NBER WORKING PAPER SERIES

DO LABOR RENTS JUSTIFY STRATEGIC

TRADE AND INDUSTRIAL POLICY?

William T. Dickens

Working Paper No. 5137

\author{
NATIONAL BUREAU OF ECONOMIC RESEARCH \\ 1050 Massachusetts Avenue \\ Cambridge, MA 02138 \\ May 1995
}

I would like to acknowledge the generous research support of The Brookings Institution, the National Commission for Employment Policy, the Institute of Industrial Relations at Berkeley, the Economic Policy Institute and the Center for German and Western European Studies at Berkeley. This paper benefitted from the able research assistance of Michael Barnes, Gustavo Gonzaga, Sharon Hoke, Bryan Lincoln, and Steven Raphael, and from many helpful conversations with Kevin Lang. The paper also benefitted from presentations at The Brookings Institution, U.C. Irvine, Princeton, University of Maryland and at U.C. Berkeley. This paper is part of NBER's research programs in International Trade and Investment, and Labor Studies. Any opinions expressed are those of the author and not those of the National Bureau of Economic Research.

(C) 1995 by William T. Dickens. All rights reserved. Short sections of text, not to exceed two paragraphs, may be quoted without explicit permission provided that full credit, including () notice, is given to the source. 


\title{
DO LABOR RENTS JUSTIFY STRATEGIC TRADE AND INDUSTRIAL POLICY?
}

\begin{abstract}
Several efficiency wage theories of wage determination have the property that identical workers are more productive in high wage industries and that the promotion of employment in high wage industries can increase GDP (and some measures of welfare). I argue that while policies to favor high wage industries may increase productivity, the effects in developed economies are likely to be very small. This is mainly because the workers who fill the high wage vacancies will come from fairly high wage jobs.
\end{abstract}

William T. Dickens

The Brookings Institution

1775 Massachusetts Avenue

Washington, DC 20036

and NBER 
Do Labor Rents Justify Strategic Trade and Industrial Policy?

by

William T. Dickens

Over the last decade, developments in the theory of wage determination have lead several authors to suggest that interindustry wage differences in developed countries may justify industrial and strategic trade policy (Bulow and summers 1986 , Dickens and Lang 1988, Katz and Summers 1989). These studies argue that large wage differences between industries are not entirely due to differences in workers' ability or the desirability of the jobs. It is said that the higher wages reflect economic rents workers receive in their jobs. Industries that pay higher wages use less labor than they would if they faced the same price of labor as lower wage industries. As a result, the marginal revenue product of identical workers is higher in the high wage industry than in the low wage industry, and moving workers from the low to the high wage industry can increase the average productivity of 1 abor ${ }^{1}$.

The first-best way to move labor from low wage to high wage industries would be to subsidize the wages in the high wage

\footnotetext{
${ }^{1}$ In general, such policies can not accomplish pareto, or even compensated pareto, increases in welfare. Instead the weaker welfare criteria of increased value of total output is used to justify such policies. See Bulow and summers for a discussion of the issue of the appropriate welfare criteria for evaluating the effects of policy in non-market clearing models.
} 
industry. However, large scale subsidies to the wages of relatively well-off workers are thought politically impractical, so discussion has focused on trade and industrial policy as ways to help the industries that employ high wage workers.

Previous studies have made the case that differences in the wages between industries are not due to workers' skills and/or the desirability of jobs (see Dickens and Lang 1993 for a review). This paper examines the implications of that finding for trade and industrial policy.

There are four necessary conditions for labor rents to justify trade policy or industrial policy:

1. Workers' productivity must increase when they are moved from . low to high wage industries

2. It must be possible to move workers from low to high wage industries by favoring high wage industries.

3. The rents that are captured by creating more high wage jobs must not be completely dissipated in rent seeking activities.

4. The gains to productivity must be greater than the costs of implementing the policy.

Taking as given that inter-industry wage differences are not market clearing the first condition requires that marginal 
revenue products be equal to wages or at least be higher in high wage industries. Several non-market-clearing theories of wage determination do not have this property.

The main reason the second condition might not obtain is that favoring industries with high labor rents might lead only to an increase in wages or profits (rent capture) and not to increased employment. Several models of labor rents have this property.

One of the prime motivations for the development of nonmarket clearing theories of wage determination is their ability to explain unemployment. However, to the extent that unemployment entails the dissipation of rent through search or other unproductive activities it means that attempts to increase rents available in the economy may have the undesirable side effect of increasing unemployment. In many models -- such as Harris-Todaro (1970) -- rent dissipation is complete, so increasing the number of high wage jobs has no positive impact on the productivity of the economy.

The fourth condition raises the empirical issue of the size of rents relative to the cost of distortions created by the policies adopted to favor high wage industries. It also raises the question of the magnitude of rent capture and rent dissipation.

This paper considers each of these four points in order below. I conclude that it is reasonable to believe that wages are non-market clearing and that marginal revenue products are 
approximately equal to wages. Rent capture should not be a problem if policies are designed taking this consideration into account. There is little evidence of significant rent dissipation in unemployment. But, I find that the potential gains from increasing the output of high wage goods in the United states is surprisingly small. The main reason for this finding is that, when the high wage sector of a developed economy is expanded, workers in the sectors which contract are also likely to be earning substantial rents. This is particularly true for the effects of trade policy. There may still be opportunities for policy to increase welfare by increasing the number of workers in high-wage/high-productivity jobs, but they will be rare and their effects small.

\section{Can Moving Workers Between Industries Increase Productivity?}

When similar workers in different industries are paid different wages one might expect that their marginal products are different. However, wage differences for similar workers do not ensure that moving workers from low to high wage industries will increase their productivity. For example, if all inter-industry wage differences were due to union wage premiums, and unions and firms negotiated contracts which were strongly efficient, then

${ }^{2}$ Brown and Ashenfelter (1986) define a strongly efficient contract as one where the level of employment is set at the point where the marginal product of labor in the firm is equal to the opportunity cost of time to the workers, and the wage simply divides any surplus the firm earns between workers and the firm. Several different models of bargaining will give rise to strongly efficient contracts. 
the marginal revenue product of labor will be set equal to labor's opportunity wage in all industries. Thus there will be no gain to productivity in moving workers from low to high wage industries since the productivity of the marginal worker in all industries is equal to the opportunity cost of labor in the economy, just as it would in a market clearing model.

This is not the unique property of the efficient contracts model. If non-union workers' wages are determined by the threat of unionization it is possible that marginal revenue products will be lower than the opportunity cost of labor (Dickens, 1986). Alternatively, a normative model of wage determination in which workers expect to receive a share of the profits of the firm may also yield the result that the profit maximizing firm sets the marginal revenue product of labor equal to the reservation wage. ${ }^{3}$ In both the union threat and the rent sharing model this occurs because firms recognize that by increasing employment they reduce profits per worker and therefore the cost of labor." Thus they expand employment beyond the level they would if they faced a fixed high wage.

\footnotetext{
${ }^{3}$ Specifically, if the wage is set as $w=r+a(R(L) / L-r)$ and profits are $p=R(L)$ - wL, where $r$ is the reservation wage, $R(L)$ is revenue net of non-labor costs, $L$ is employment and $a$ is labor's share of profits, then substituting the wage determination equation into the profit equation yields:
}

$$
p=(1-a)(R(L)-r L) \text {. }
$$

Maximization of this yields $R^{\prime}=r$.

${ }^{4} T$ The effect is the same as what wietzman (1984) hopes to accomplish by encouraging firms to share profits with workers. 
Most shirking, or worker retention, efficiency wage models would give the result that wage is equal to marginal revenue product. This suggests that we need to know the exact form of the wage determination mechanism before we could know whether moving workers would increase productivity. This may not be the case.

Above I described two types of non-market clearing models which do not yield the equation of marginal revenue products and wages: models with explicit bargaining of efficient contracts, and some models of rent-sharing or rent-extraction without explicit bargaining. In theory efficient bargaining could lead to the equalization of marginal products across industries, but most evidence suggests that bargained wage/employment pairs are close to, or on, the labor demand curve. This would mean that wages were nearly or exactly equal to marginal revenue products. One type of study has examined the relation between employment, own wages and reservation wages of union workers (Brown and Ashenfelter 1986, Card 1986, Svenjar 1986). These studies find little or no response of employment to the reservation wage and a strong negative response of employment to own wages. This is what one would expect if bargains were on the labor demand curve. MaCurdy and Pencavel (1986) specify a structural model of the firm and the bargaining process which they estimate to determine if contracts are efficient. They conclude that contracts are not on the labor demand curve, but that they are not far from it. Abowd (1989) examines the response of the stock 
market value of union firms to the outcome of wage bargaining and concludes that there is no evidence against efficient bargaining. However, his test has almost no power against very reasonable alternative models in which bargains are on the labor demand curve. ${ }^{5}$ Finally, Bils (1991) shows that employment changes considerably when a new contract is negotiated that changes wages. This is inconsistent with contract efficiency where the wage is not allocative.

Why should firms and workers be negotiating inefficient contracts? There are several possible explanations. First, staiger (1990) has argued that since bargaining over employment is not mandatory under U.S. labor laws it is up to the firm whether it is included in bargaining. Although the total surplus is larger with an efficient bargain, the firm's profits

\footnotetext{
${ }^{5}$ Abowd shows that if unions increase wages, profits will decrease less than dollar for dollar and if unions take a wage cut profits will increase more than dollar for dollar if contracts are on the labor demand curve. He regresses the unexpected change in the stock-market value of the firm on the unexpected change in the wage times the initial labor force and tests whether the coefficient on positive changes is the same as the coefficient on negative changes. The test is very weak because the standard errors on the coefficients are large relative to the deviation from equality one would anticipate on the basis of theory. Under vary favorable assumptions (labor share of value added is 70\%, an elasticity of demand for labor of $10,10 \%$ real wage increases, no covariance between the wage increase and wage decrease, and a standard error equal to the lowest of any of his estimated coefficients) we would expect Abowd's method to reject the false hypothesis of equality only about three fourths of the time. Under more reasonable assumptions (labor share at the firm equal to $40 \%$ of value added, elasticity of demand for labor of $1.3,6 \%$ real wage increases, ratio of covariance of coefficients to variance of -.25 , and standard errors of . 3 (about the average for his estimates)) a false null would be rejected less than $1 / 5$ th of the time.
} 
may not be. Thus firm's may choose the inefficient outcome.

Alternatively, Johnson (1990) suggests that imperfect

information about the level of output may lead unions and firms to write contracts which specify staffing levels for pieces of machinery rather than employment levels. Such provisions are much more common in contracts than provisions specifying contingent employment levels. Such provisions give rise to less than the optimal employment and marginal revenue products greater than the reservation wage.

Yet another set of explanations suggest that union preferences may not weight employment heavily so that efficient bargains between unions and firms are not strongly efficient. In the standard model of bargaining (such as the one described by Brown and Ashenfelter (1986)) unions will value wages more than employment if workers are risk loving. This is not a very satisfying explanation for observed behavior. However, there are several other explanations for preferences which stress wages.

One argument, due to oswald (1984), is that the median union voter is not concerned with employment because of seniority layoff rules. He shows that seniority rules are pervasive in union contracts. Arthur Ross (1948) argued that union workers have no way of knowing how well union leadership is doing in bargaining except by comparing their contract to those of workers in other firms or industries. Ross dubbed the bargaining patterns "orbits of coercive comparison." Such behavior by union members may lead union leaders to emphasize wages in bargaining. 
This last argument may also explain why normative models of wage determination, or those involving implicit bargaining, may give rise to employment-wage pairs close to the labor demand curve if not on it. If workers have imperfect information about the profitability of their own firm, and if there is information about the profitability of their firm in the wages at other firm's in their industry and related industries, then workers may form their wage expectations by looking at the wages at those other firms.

Dickens (1989) shows that a simple weighted average of the workers' unique information about their firm with the wages of the other firms is the optimal solution to the information extraction problem. Since the wages at other firms are not significantly affected by the actions of any one firm, the incentive to increase employment to reduce profits per worker is attenuated. The more valuable the information in the wages at other firms, and the more other firms there are, the greater the attenuation. In the limit, wage/employment pairs are on the labor demand curve.

This theoretical finding fits with the twin observations that workers' perceptions of what constitutes a fair wage are influenced by how well a firm is doing (Khaneman et. al. 1986) and firms consider equity, what other firms in their industry are paying, and their ability to pay in making compensation decisions (Levine 1993).

Thus for practical purposes it is likely that wages and 
marginal revenue products are closely linked, if not equal so that moving workers from low to high wage industries should increase their productivity.

II. Will Favoring High Wage Industries Increase Employment? The welfare effects of the Japanese Auto VERs of the $1980 \mathrm{~s}$ are hotly debated, but one thing that is not is that U.S. auto prices rose after they were established (Crandall, 1987). These higher prices increased profits and possibly wages, but they reduced the employment effects of the VERs. If industries which receive favored treatment use those favors to increase profits and wages without increasing output, then there is no gain in labor rents from favoring high wage industries. Of course it is possible that the U.S. auto industry increased its output when the VERs were put in place, ${ }^{6}$ and that the VERs were partially successful in increasing high wage employment. It becomes an empirical question whether the gains are worth the cost.

However, this issue need not even arise if policies are designed to avoid this problem. If favored treatment is never granted without spelling out what the quid pro quo will be in terms of employment increases, and wage and profit restraints, then we need not be concerned with this issue.

\section{Will Rents Be Dissipated in Unemployment?}

\footnotetext{
${ }^{6}$ Mannering and Winston (1987) argue that auto VERs reduced employment in the industry, but Dixit (1988) finds that optimal tariffs could increase output and employment.
} 
Several models in which unemployment is caused by the failure of wages to clear markets suggest that rent dissipation through unproductive rent seeking activities may be complete. For example, in the Harris-Todaro (1970) model there are two sectors -- a market clearing low wage sector and a sector with an exogenously set high wage. To apply for work in the high wage sector people must forgo productive work in the low wage sector and take a chance of being unemployed. All unemployed workers have an equal probability of being chosen for employment in the high wage sector. The result is that all of the increase in productivity that might obtain from increasing the number of high wage workers with high marginal products is lost when an increased number of low wage workers quit to be unemployed.

Again, this is not a characteristic unique to this model. Dissipation of rents is complete even when search from the low wage sector is allowed if there is some unemployment. Lang and Dickens (forthcoming) develop a two sector bilateral search model of unemployment in which subsidization of high wage sectors can be welfare reducing or enhancing depending on parameter values. On the other hand, if high wage jobs exist for which there is no way to dissipate rents in attempting to acquire them, the creation of such jobs need not lead to rent dissipation. For example, if high wage jobs are allocated to the relatives and friends of current employees, and such people do not have to be unemployed or expend much energy in search to be eligible for those jobs, then no rents will be dissipated if such jobs are 
created. Many jobs are found this way. Corcoran et. al. (1980a) report that about 60 to 708 of blue collar men "heard about their current job from a friend or relative," and about 408 of all men "received help in getting their job" from a friend or relative. Datcher (1983), Corcoran et, al. (1980b), Ullman (1968), and Granovetter (1974) provide evidence that an even higher fraction of good jobs for all types of workers come through contacts. For there to be rent dissipation it must also be the case that unemployment must be unproductive. In a Harris-Todaro (1970) model, rent dissipation occurs because people must forego productive work in the agricultural sector to queue for employment in the city. In search models, the time spent unemployed is used in search which does not necessarily produce any social value. However, unemployed people in developed countries engage in activities which are not very different from those who are out of the labor force. Only about 4 hours a week is spent searching for jobs (Rosenfeld, 1977). Thus, the unemployed have only slightly less time to spend on non-market activities than those who choose to be out-of-the-labor-force. Given that rents per unemployed worker are quite large, $^{7}$ it seems unlikely that rent dissipation is complete. The extent of rent dissipation is then an empirical question which will be one of

\footnotetext{
${ }^{7}$ An estimate described below is that the average employed worker in the United states earns about $\$ 9,000$ per year in labor rents. With an unemployment rate of $6 \%$ that implies $\$ 141,000$ per year of rents per unemployed worker -- considerably greater than any reasonable estimate of value of time lost in search. of course an alternative interpretation is that there is complete rent dissipation but that I have overestimated rents per worker.
} 
many considerations in determining whether industrial and trade policies pass the cost-benefit test.

\section{Are Rents Big Enough to Justify Policy Intervention?}

The discussion above identified 4 questions which must be answered before an estimate of the importance of labor rents for policy can be made: First, to what extent do apparent rents -gross wage differences between industries -- represent actual rents? Second, how close are marginal revenue products to wages? Third, to what extent will favoring an industry lead to employment increases rather than rent capture? Fourth, what fraction of rents will be dissipated in rent seeking activities?

The question of what fraction of differences between average wages in different industries reflect rents is a very difficult one. The theoretical problems in measuring labor rents are at the root of the debate over the nature of wage determination. The contribution of this paper is not in resolving these questions, but in providing some estimates of the potential importance of labor rents.

with respect to the second consideration, I will simply assume that wages equal marginal revenue products as a reasonable approximation. To the extent that differences in marginal products are smaller than wage differences the results will overstate the importance of rents.

The third consideration, the possibility of rent capture by workers or firms, I will ignore on the grounds that well designed 
policies can avoid, or at least significantly attenuate rent capture.

The fourth problem, the extent of rent dissipation in rent seeking, is an interesting empirical question, but one which is beyond the scope of this paper. Again, I will assume that there is no dissipation, but to the extent that there is, the estimates of the importance of labor rents for trade and industrial policy will be overstatements.

A first step towards determining the potential gains from industrial and trade policy is to determine the amount of labor rents in the value of output in different industries, or the shadow costs of goods. Once we know the shadow costs, assumptions about the elasticity of demand for goods will allow us to assess the potential for increasing productivity through trade and industrial policies.

To do this I take the following steps: First, the amount of labor from each industry which is used in the production of one dollars worth of each commodity is estimated using a U.S. inputoutput table and estimates of average labor productivity. Then two different estimates of the amount of labor rents generated per worker in each industry are used to determine the value of labor rents in each dollar of output in each industry. Finally, an attempt is made to determine where workers will come from to fill jobs when output in an industry is increased and what the net generation of labor rents will be.

To compute the labor use from all industries that results 
from an increase in demand in one industry, standard input-output techniques are used with one modification. The U.S. Department of Commerce's 85 sector 1986 industry-commodity-requirement matrix from the U.S. input-output accounts was augmented with Bureau of Economic Analysis figures on the use of investment goods by I-O sector and depreciation as a faction of the value of output. ${ }^{\theta}$ That information lists, for each I-O sector, the fraction of investment goods coming from each other I-O sector. Capital use as a fraction of the value of output was set equal to the value of depreciation in output. ${ }^{9}$

Using Department of Commerce notation, a matrix $C$ was constructed which has for each column the dollar value of the products of each industry used in the production of a particular commodity:

$$
C=W(I-(B+Z K) W)^{-1}
$$

where $W$ is the industry-by-commodity to commodity-by-commodity transformation matrix, $B$ is the commodity use by industry matrix and $\mathrm{K}$ is our matrix of capital use by industry. $\mathrm{z}$ is a matrix

\footnotetext{
${ }^{8}$ The capital flows data was constructed in 1977 and is from an internal BEA memo. Depreciation figures are published BEA $(1987)$.

${ }^{9}$ Two alternative calculations were done in which capital use was set equal to the a fixed fraction of a BEA estimate of the size of the capital stock in each I/O industry and another in which it was set equal to capital's share in the value of output in each industry. Results were substantively the same with respect to the magnitude of rents and the ranking of industries.
} 
created from which translates capital flows from industry to industry into a matrix in which each column shows the capital use by commodity category for an industry ${ }^{10}$.

A column vector equal to the average number of workers per dollar of output in each industry was then created. From that a matrix $E$ with the same dimensions as $C$ was constructed by concatenating copies of the column vector of workers per dollar of output. Multiplying $\mathrm{E}$ times $\mathrm{C}$ on an element by element basis yields a matrix which gives person years of work in each industry for a dollars demand for each commodity. We will call this matrix L.

Next, two measures of labor rents per worker year in each industry were created. The first simply took raw differences in compensation per worker between each industry and the industry with the lowest compensation per worker (agriculture) and treated these as labor rents. For all the reasons discussed above these are most likely overestimates of the true differences between industries in labor rents.

An alternative measure attempts to take into account differences in the productivity of workers with different observable characteristics. This measure is constructed by regressing the natural 1 og of individual wages on a wide range of

$10 \quad Z$ is defined as:

$$
z_{1 j}-w_{1,} q_{j} /\left(w_{1}, q\right)
$$

where $q$ is a column vector of the total output of each commodity and $w_{1}$. is the $i$ th row of $w$. 
individual characteristics and industry dummy variables. ${ }^{11}$ The difference between the predicted wages in each industry for a worker with average characteristics, and that person's predicted wage in the industry with the lowest predicted wage for the average worker (eating and drinking places) is taken as the measure of the dollar value of rent per hour of work. The proportion of rent in annual total compensation was assumed to be equal to the proportion of rent in wages in each industry. Table 1 presents these two measures of rents for 77 I-O industries. The second measure yields estimates about half the size of the first.

Unfortunately, the second method can not reliably be said to provide an under or over estimate of the true extent of labor rents -- even ignoring the issues of rent dissipation and the equality of marginal products and wages. On the one hand, it assumes that unobserved aspects of ability are orthogonal to industry. This is certainly not the case as there is notable sorting of more able workers into high wage industries on the basis of observable measures of ability. This would suggest that the second method yields over estimates of the extent of rents, but this is not necessarily the case.

Only if the individual returns to observable characteristics represent the social return is it appropriate to control for them. For example, suppose that there are only infinitismal

\footnotetext{
${ }^{11}$ See Dickens and Katz (1987) for a complete description of the method and 1 ist of variables in the regression.
} 
differences in the productivity of workers with different levels of education. In a model where wages are determined by implicit bargaining, an employer who must pay high wages will be able to choose workers with more schooling to partially offset the expense of the higher wage. The estimated return to education will reflect the advantage an educated worker gets in being higher up in the queue for good jobs, and not the true infinitismal social return to education. Thus part of industry rents will be attributed to education inappropriately. In this case the regression corrected estimates will under estimate true rents.

In what sorts of non-market-clearing models of wage determination will social return and individual return be equated? This would seem to be true for most efficiency wage models where an individual's wage increases dollar for dollar with his/her reservation wage. However, in bargaining models wages tend to rise less than one for one with reservation wages. This also provides the incentive for higher wage employers to employ more able workers. Unfortunately, the bargaining, or rent-extraction models, fit better with the facts than the standard economic efficiency wage models. ${ }^{12}$ Thus we are left with one set of rent figures which are clearly over estimates, and another which might provide either over or under estimates. Luckily, having an upper bound will allow us to make a judgement about the usefulness of labor rents as a justification of

\footnotetext{
${ }^{12}$ See the discussion in Dickens and Lang(1993).
} 
strategic trade policy.

The second two columns of table 1 show what happens when we multiply the L matrix (labor requirements by commodity) times the two labor rent vectors. This gives us an estimate of the fraction of the value of the commodity which is labor rents. The employment and output weighted average for the 77 I-O industries are both .35 for the rent measure based on raw compensation, and .20 for those based on the regression corrected estimates. These are large fractions. One could interpret these to mean that the shadow price of the average good in the economy could be as little as 65 cents on the dollar.

This immediately raises the question of where the workers who would fill newly created high wage jobs are coming from, or, more precisely, what isn't getting done when more people are employed in the high wage sector. ${ }^{13}$ only if the opportunity cost of their time is equal to the compensation in the lowest wage industry is the labor rents measure the correct one to use for evaluating policy.

This would be the case only if the U.S. economy was a Lewisian labor surplus economy. While this may be an attractive

\footnotetext{
${ }^{13}$ The existence of mobility chains (Akerlof, Rose and Yellen 1988) make the exercise of determining the shadow cost of the time of those effectively filling newly created jobs more difficult than just looking where the people filling the job came from. It is possible that their old jobs are in turn filled by people with still lower wage jobs whose jobs are filled by even people with even still lower wages and so on. The question is where ultimately does employment contract or what is the opportunity cost of time of people who enter the labor force as a result of the increased demand.
} 
way to model developing economies with large subsistence agriculture sectors, it seems more likely that an increase in the demand for labor in one industry would lead to a bidding up of wages generally and a reallocation of labor between industries in the U.S. economy. Thus, the worker filling a job created by an increase in demand in any sector of the economy would be coming from some weighted average of all industries.

A measure of labor rents in the value of goods in an industry which was net of the opportunity cost of the labor used would be a close approximation to what one would want to for evaluating industrial policies which changed the allocation of domestic product demand. It would not be precisely correct since it would not take into account the general equilibrium consideration of how the revenue for a subsidy was being raised or where the revenue from a tax was being spent.

In one very simple model it is possible to identify where labor would come from to satisfy an increased demand for labor in one sector. Suppose that the share of income spent by consumers on each good is a function of relative prices but not income, and that total demand for all goods is:

$$
d=s(p)(Y-T)+g
$$

where $\mathrm{d}$ is the vector of demand for commodities, $\mathbf{s}$ is the vector of shares of income spent on each commodity, $Y$ is income, $T$ is tax revenue, and $g$ is the vector of government demand. Suppose 
further than all inputs except labor are supplied at constant prices. Wages in each industry are fixed, and a fixed supply of labor is available in the economy at a reservation wage below the lowest wage offered by any of the industries. Assuming constant returns to scale in the production of all goods, and perfect competition in product markets, each good will be priced at average cost which will be constant.

If we then ask what will happen to the employment of labor in each industry if government demand is increased in any one industry the answer is that private demand will fall by the same fraction in all industries since prices are constant and, consequently, the share of disposable income spent on each good is constant. Thus the shadow cost of labor to any one industry is equal to the average wage in employment induced by private demand. Defining a as this average, the vector of ratios of the value of labor rents embodied in each good to the price of each commodity is :

$$
c=(r-a) \cdot L
$$

where $L$ is defined above, and $r$ is the vector of the value of labor rents.

Computed values for $c$ are presented in Table 2 . Column 1 presents values computed using labor rents calculated from total compensation, while column 2 present values computed using the measure of rents that is corrected for individual 
characteristics.

A striking finding is how low price is relative to shadow costs in two industries -- eating and drinking places and hotels and personal services. Governments spend a great deal of money to promote both domestic and international tourism. Much of the money spent by tourists is spent in these two industries. These results suggest that government's interest in promoting tourism may be misplaced.

In a few industries, increased production could lead to at least modest productivity gains. However, a few cautions are in order. First, the group of industries with some of the lowest shadow costs as a fraction of price are the extractive industries. It is possible that a substantial fraction of what appear to be labor rents in these industries are actually compensating differentials for dirty and dangerous work. Outside of extractive industries only ordinance, computing equipment, and communications have shadow costs less than 90 percent of price in column 2 (labor rents computed using compensation corrected for individual characteristics). Both ordinance and communications are idiosyncratic industries. The shadow costs of sales would be only one consideration in forming public policy towards these industries. Finally, the estimates of increased productivity from increasing output of these goods would only be appropriate if the goods were produced domestically for domestic consumption and did not replace imported goods.

In the case of traded goods, we know that policies that 
affect our imports or exports of particular goods will also affect the quantities of other goods imported and exported. There will be at least a tendency for a decrease in imports of one good to be offset by an increase in the imports of others or a decrease in the export of other goods to maintain a constant level on the current account. If we pursue a policy to promote exports in strategic industries, we must expect that we will export less of some other goods, or import more. The increased imports will crowd out domestic production in those industries. Since the concern is with the long run effects of reallocating demand between industries it is assumed that current account will remain unchanged when exports or imports are manipulated by policy. This is the most important consideration in determining the opportunity cost of time of workers who fill jobs in industries where demand is increased by a hypothetical trade policy -- most of the workers are coming from other traded good industries where demand is decreasing.

Labor rents are a larger fraction of value in traded goods industries. Using the raw compensation measure $42 \%$ of value in traded goods is labor rents (compared with $35 \%$ for all goods). Using the corrected compensation measure $22 \%$ of value in traded goods is labor rents (compared with $20 \%$ for all goods). Thus, the shadow cost of increasing trade in the average industry will be greater than the value of the increased output. But, advocates of strategic trade policy are not suggesting that we subsidize the average industry. Is it possible to pick 
industries in which the shadow cost of output is substantially bellow the value we would get for the good in trade?

To answer this question several measures of labor rents net of the opportunity cost of workers' time by industry were created. These measures were constructed as follows. First, estimates of the price elasticity of demand for U.S. exports and the U.S. price elasticity of demand for foreign imports were constructed using data on imports and exports for the 1980 s along with trade weighted indexes of the U.S./world exchange rate and U.S. and world GDP. Logs of the value of imports and exports in each sector were regressed on the log of the exchange rate and U.S. or foreign GDP respectively. The likelihood function was maximized subject to the constraint that the Lerner condition was satisfied. When this condition was imposed all exchange rate elasticities had appropriate signs.

Labor rent measures for each commodity were then constructed as :

$$
R_{j} / V_{j}=(r-a) \cdot\left(L_{j}-L d\right) \text {. }
$$

where R./V. denotes labor rents as a fraction of the value of the good, $r$ is the vector of labor rents per worker year, a is a conformable vector equal to the average value of $r$, L. denotes a column of the matrix L (the labor use by industry for each commodity) and $d$ is defined as:

$$
d_{j}=.5\left(e_{j} m_{j} /\left(e^{\prime} m\right)+f_{j} x_{j} /\left(f^{\prime} x\right)\right) \text {. }
$$

where $e$ is the vector of the absolute value of the elasticities of demand for each commodity in imports, $f$ is the absolute value 
of the elasticity of demand for or exports, $m$ is the vector of the dollar value of U.S. imports and $x$ is a vector of the dollar value of U.S. exports.

With the assumption of complete crowding out on the current account, the d vector can be interpreted as the amount demand in each industry will decline if there is a one dollar exogenous increase in the exports of one particular good. Equal weighting of imports and exports is suggested by analysis of data from the 80's which shows that, on average, changes in the trade deficit were accomplished with about equal absolute changes in imports and exports.

$L_{y}-L d$ gives us the reallocation of labor between traded good industries that results from increasing exports of commodity $j$ by one dollar. Multiplying this times the vector of rents per worker year yields the value of rents created, or lost, by this reallocation. Since the number of workers hired when demand for commodity $j$ expands is not necessarily equal to the number of workers who lose jobs from the reduction in demand for other traded goods, it is assumed that if the sum of the column $L_{j}-L d$ is greater than zero the workers come from a job with the average labor rents per worker, and that if it is less than zero that they go to a job with the average labor rents.

Columns 1 and 2 of table 3 present the estimates using the two different measures of labor rents defined above. Columns 3 and 4 present a measure constructed assuming that imports of each commodity expand, and exports contract, in proportion to their 
current shares of trade, or that $R . / V$. is constructed using, in place of $d, d^{*}$ defined as:

$$
d_{j}^{*}=.5\left(m_{j} /\left(i^{\prime} m\right)+x_{j} /\left(i^{\prime} x\right)\right) .
$$

where $i$ vector of ones.

The results are not encouraging for those who would argue for favoring strategic industries on the basis of labor rents. Ignoring extractive industries, since their measures of labor rents undoubtedly ignore some component of compensating difference for work quality, and ignoring ordnance because of the complicated political issues involved in promoting arms sales, the largest fraction of labor rents in value are for aircraft. Considering only labor rents ${ }^{14}$, the shadow cost of aircraft is at most $13 \%$ less than the market price. Using the corrected labor rent measure, shadow cost is less than $5 \%$ below market price. Thus, elasticity of demand for U.S. aircraft exports would have to be 7 or greater for an export subsidy to improve U.S. welfare. It is even harder to make the case in other industries which have been suggested as targets for promotion. Motor vehicles would have to have an elasticity of demand of over 10 , consumer electronics over 12, and computing equipment over 14 .

\section{v. Conclusion}

Although it would seem that labor rents might provide a powerful justification for the use of strategic trade and

\footnotetext{
${ }^{14}$ The price of aircraft also represents monopoly rents which are captured in profits. Product market rents not captured by workers would not be taken into account in these calculations.
} 
industrial policy, in practice they do not. The potential for trade and industrial policy to increase productivity by increasing employment in high labor rent industries is very limited. This is mainly because the average good produced in the U.S. -- and particularly the average traded good -- is quite high in labor rents. Increasing domestic production of one good requires labor taken from other uses. Increasing our exports of any good ultimately means reducing our exports of something else or increasing our imports and crowding out domestic production. Consequently, the labor rents created by moving workers into high wage jobs, net of the rents lost when other high wage jobs go unfilled, is quite small in all the industries analyzed here. There is little reason to believe that much advantage could be gained from policies to promote some industries over others considering only labor rents.

still, there are some lessons. If other countries want to restrict our exports of agricultural goods, it seems unlikely that the effects on our terms of trade would be sufficiently large to overcome the disadvantage to us of a shadow cost of agricultural exports as much as 208 more than the market price ${ }^{15}$.

While the extremely high elasticities of demand necessary to justify exports subsidies might not be present, it is possible

\footnotetext{
${ }^{15}$ of course as long as the United states has a surplus of agricultural goods created by our own wasteful agricultural policies, dumping them on foreign countries at any price is better than throwing them away from the point of view of our national welfare. The results cited above make it even more clear that our system of agricultural supports work against our national interest.
} 
that some small advantage could be gained from subsidies on increments to exports. It is also possible that government support which creates an industry in a country, such as the European subsidies to Airbus Industries did, could be welfare enhancing. Dickens (1993) reconsiders the Airbus subsidies and concludes that they may have added a few miliion dollars to the GDPs of Airbus member countries. A similar advantage might be gained if, through small pre-competitive government funding, the U.S. were able to capture a significant share of the market for HDTV . 


\section{References}

Abowd, John M. (1989) "The Effect of Wage Bargains on the Stock Market Value of the Firm," American Economic Review, 79 (4) September, p774-800.

Akerlof, George A., "Gift Exchange and Efficiency Wage Theory: Four Views," American Economic Review, 74 (May 1984): 79-83.

Akerlof, George A., Andrew K. Rose, and Janet L. Yellen (1988), "Job Switching and Job Satisfaction in the U.S. Labor Market," Brookings Papers on Economic Activity, (2) p495-582.

Brown, James $N$, and orley Ashenfelter (1986), "Testing the Efficiency of Employment Contracts," Journal of Political Economy, 94 (3) Part 2, (June) ps40-S87.

Bulow, J.I., and L.H. Summers. "A Theory of Dual Labor Markets with Application to Industrial Policy, Discrimination and Keynesian Unemployment." Journal of Labor Economics 4 (July $1986): 376-414$

Bureau of Labor Statistics (1975), Jobseeking Methods Used By American Workers, Bulletin 1886 (GPO).

Cain, Glenn. 1976. "The Challenge of Segmented Labor Market 
Theories to Orthodox Theory," Journal of Economic Literature, Dec. , $14: 1215-1257$.

Card, David (1986) "Efficient Contracts with Costly Adjustment: Short-Run Employment Determination for Airline Mechanics," American Economic Review, 76(5) (December) p1045-1071.

Corcoran, Mary, Linda Datcher, and Greg J. Duncan (1980a), "Most Workers Find Jobs Through Word of Mouth," Monthly Labor Review, $103(8)$ (November) p33-35.

Corcoran, Mary, Linda Datcher, and Greg J. Duncan (1980b), "Information and Influence Networks in Labor Markets," in Greg $J$. Duncan and James N. Morgan (eds.), Five Thousand American Families -- Patterns of Economic Progress, Vol. VIII (Ann Arbor: Institute for Social Research).

Crandall, Robert W. (1987) "The Effects of U.S. Protection for Autos and Steel," Brookings Papers on Economic Activity. p671-715.

Datcher, Linda (1983), "The Impact of Informal Networks on Quit Behavior," The Review of Economics and Statistics, 65 (3) (August) p491-495.

Dickens, William T., "Wages, Employment and the Threat of 
Collective Action by Workers," NBER working paper, 1986.

"Does it Matter what We Trade? Trade and

Industrial Policies when Labor Markets Don't Clear," Industrial

Relations Research Association Series, Proceedings of the Forty-

Second Annual Meetings, December 28-30, 1988, Atlanta, p527-535.

(1993) "The U.S. Labor Market Impact of European

Economic Integration," in Dickens, Eichengreen and Ulman eds.

Labor Market Responses to European Economic Integration,

Washington D.C.:Brookings.

Dickens, William T., and Katz, Lawrence F. (1987). "Industry Wage Differences and Theories of Wage Determination," NBER Working Paper 2271 .

Dickens, william T. and Kevin Lang (1993) "Labor Market

Segmentation Theory: Reconsidering the Evidence," in William Darity Jr. Labor Economics: Problems in Analyzing Labor Markets, Boston: Kluwer, p141-180.

\footnotetext{
(1988) "Why it Matters What we

Trade: A Case for Active Policy," The Dynamics of Trade and

Employment, L. Tyson, W. Dickens and J. Zysman eds. Cambridge MA. Ballinger.
} 
Dixit, A. 1988 "Optimal Trade and Industrial Policy for the U.S. Automobile Industry," in Empirical Methods for International Trade, Robert C. Feenstra, ed. Cambridge:MIT., pp141-65

Granovetter, Mark (1974), Getting a Job: A Study of Contacts and Careers, (Cambridge: Harvard).

Harris, J. and M. Todaro (1970), "Migration, Unemployment and Development," American Economic Review, 60 (March) p162-142.

Johnson, George E. (1990), "Work Rules, Featherbedding, and Pareto-Optimal Union Management Bargaining," Journal of Labor Economics, 8(1) (January), Part 2, S237-259.

Kahneman, D., Jack L. Knetsch, and R. Thaler, "Fairness as a Constraint on Profit Seeking," American Economic Review, Vol. 76, \#4, (September, 1986) p728-741.

Katz, Lawrence F. and Summers, Lawrence H. 1989. "Industry Rents: Evidence and Implications," Brookings Papers on Economics Activity: Microeconomics 1989, p209-275.

Lang, Kevin, and William T. Dickens (forthcoming), "Labor Market Segmentation, Wage Dispersion, and Unemployment," in The Modern Analysis of Unemployment, D. Snower and J. Stiglitz eds. also 
NBER working paper No. 4073 (1991).

Levine, David I. "Fairness, Markets, and Ability to Pay: Evidence from Compensation Executives," American Economic Review, Vol. 83, \#5 (December, 1993) p1241-1259.

MaCurdy, Thomas E. and John H. Pencavel (1986), "Testing Between Competing Models of Wage and Employment Determination in Unionized Markets," Journal of Political Economy, 94(3) (June) ps3-s39.

Mannering, Fred and winston, Clifford (1987), "Economic Effects of Voluntary Export Restrictions," in Blind Intersection? Policy and the Automobile Industry, clifford Winston and Associates (eds.) Brookings:D.C. .

Oswald, Andrew J. (1984) "Efficient Contracts are on the Labor Demand Curve," Princeton IR Section WP \#178.

Rosenfeld, Carl (1977) "Job Search and the Unemployed; May, 1976" Monthly Labor Review, (November).

Ross, Arthur (1948) Trade Union Wage Policy, Berkeley California: University of California Press.

Staiger, Douglas (1990) Three Essays in Labor Economics, M.I.T. 
Ph.D. dissertation.

Svejnar, Jan (1986), "Bargaining Power, Fear of Disagreement, and Wage Settlements: Theory and Evidence from U.S. Industry," Econometrica, 54(5) (September) p1055-1078.

Ullman, J.C. (1968), "Interfirm DIfferences in the Cost of Search for Clerical Workers," Journal of Business, 41 (January) p153165.

Wietzman, Martin L. (1984), The Share Economy, Cambridge:Harvard. 
Table 1

Labor Rents by Commodity

\begin{tabular}{|c|c|c|c|c|c|}
\hline \multirow{2}{*}{\multicolumn{2}{|c|}{ Commodity }} & \multicolumn{2}{|c|}{$\begin{array}{c}\text { Rents per Worker } \\
\text { Year (19935) }\end{array}$} & \multicolumn{2}{|c|}{$\begin{array}{c}\text { Rents as Fraction } \\
\text { of Value }\end{array}$} \\
\hline & & \multirow{2}{*}{$\frac{\underset{\text { Raw }}{\text { Compens. }}}{\$ 1,783}$} & \multirow{2}{*}{$\begin{array}{c}\begin{array}{c}\text { Cor. } \\
\text { Compens. }\end{array} \\
\$ 2,377\end{array}$} & \multirow{2}{*}{$\frac{\begin{array}{c}\text { Raw } \\
\text { Compens. }\end{array}}{.231}$} & \multirow{2}{*}{$\frac{\begin{array}{c}\text { Cor. } \\
\text { Compens. }\end{array}}{.142}$} \\
\hline 1 & Livestock and products & & & & \\
\hline 2 & Other agricultural products & 0 & 2,377 & .200 & .134 \\
\hline 3 & Forestry and fisheries & 4.445 & 2,377 & .263 & .153 \\
\hline 4 & Agricultural services & 1,254 & 2.377 & .236 & .179 \\
\hline 5 & Iron and ferroalloy ores & 28,461 & 14,452 & .641 & .344 \\
\hline 6 & Nonferrous metal ores & 22,372 & 14.452 & .626 & .370 \\
\hline 7 & Coal mining & 25,639 & 16,122 & .507 & .299 \\
\hline 8 & Crude Petroleum and gas & 27,920 & 13,714 & .224 & .124 \\
\hline 9 & stone and clay mining & 14,333 & 9.475 & .392 & .233 \\
\hline 10 & Chemical and fertilizer & 18,092 & 9.475 & .343 & .184 \\
\hline 11 & New construction & 13,822 & 9,475 & .426 & .258 \\
\hline 12 & Repair and Maintenance & 15,936 & 9,475 & .432 & .248 \\
\hline 13 & ordnance and accessories & 24,189 & 12,687 & .586 & .308 \\
\hline 14 & Food and kindred products & 14,670 & 6,745 & .306 & .162 \\
\hline 15 & Tobacco manufactures & 15,989 & 11,980 & .147 & .096 \\
\hline 16 & Broad and narrow fabrics & 7,467 & 5,942 & .439 & .274 \\
\hline 17 & Miscellaneous textile goods & 9,140 & 7,194 & .405 & .245 \\
\hline 18 & Apparel & 3,833 & 3,212 & .331 & .220 \\
\hline 19 & Misc. fab textile products & 7,880 & 3,853 & .404 & .230 \\
\hline 20 & Lumber and wood products & 11,212 & 5,653 & .377 & .198 \\
\hline 21 & Wood containers & 4,308 & 5,653 & .360 & .265 \\
\hline 22 & Household Furniture & 6,369 & 5,267 & .385 & .247 \\
\hline 23 & other furniture fixtures & 11,470 & 5,267 & .402 & .200 \\
\hline 24 & Paper and Allied Products & 19,810 & 9.988 & .418 & .219 \\
\hline 25 & Paperboard containers & 13,901 & 6.745 & .408 & .208 \\
\hline 26 & Printing and Publishing & 13.706 & 6,616 & .402 & .205 \\
\hline 27 & Chemicals & 23,386 & 12,236 & .384 & .204 \\
\hline 28 & Plastics and synthetics & 24.089 & 10,246 & .483 & .246 \\
\hline 29 & Drugs, cleaning \& toilet & 20.668 & 10,277 & .358 & .190 \\
\hline 30 & Paints and allied products & 17.794 & 8,897 & .387 & .201 \\
\hline 31 & Petroleum refining & 29.592 & 14.388 & .257 & .138 \\
\hline 32 & Rubber and miscellaneous & 13,022 & 7.740 & .433 & .239 \\
\hline 33 & Leather tanning and finish & 12.954 & 6,231 & .318 & 163 \\
\hline
\end{tabular}


Table 1

Labor Rents by Commodity

\begin{tabular}{|c|c|c|c|c|c|}
\hline \multirow{2}{*}{\multicolumn{2}{|c|}{ Commodity }} & \multicolumn{2}{|c|}{$\begin{array}{c}\text { Rents per worker } \\
\text { Year }(1993 \$)\end{array}$} & \multicolumn{2}{|c|}{$\begin{array}{c}\text { Rents as Fraction } \\
\text { of value }\end{array}$} \\
\hline & & \multirow{2}{*}{$\frac{\begin{array}{c}\text { Raw } \\
\text { Compens. }\end{array}}{4,028}$} & \multirow{2}{*}{$\begin{array}{c}\begin{array}{c}\text { Cor. } \\
\text { Compens. }\end{array} \\
4,624\end{array}$} & \multirow{2}{*}{$\frac{\begin{array}{c}\text { Raw } \\
\text { Compens }\end{array}}{.338}$} & \multirow{2}{*}{$\frac{\begin{array}{c}\text { Cor. } \\
\text { Compens. }\end{array}}{.251}$} \\
\hline 34 & Footwear and other leather & & & & \\
\hline 35 & Glass and glass products & 17,471 & 7,547 & .475 & .228 \\
\hline 36 & Stone and clay products & 14,362 & 7,290 & .411 & .215 \\
\hline 37 & Primary iron and steel & 25,345 & 9,250 & .468 & .209 \\
\hline 38 & Primary nonferrous metals & 19,598 & 8,768 & .401 & .202 \\
\hline 39 & Metal containers & 25,098 & 7,290 & .418 & .175 \\
\hline 40 & Heating and plumbing & 14,394 & 7,290 & .437 & .220 \\
\hline 41 & Screw machine products & 18,926 & 7,290 & .473 & .211 \\
\hline 42 & Other fabricated metal & 13,699 & 7,354 & .407 & .212 \\
\hline 43 & Engines and Turbines & 23,195 & 12,140 & .452 & .231 \\
\hline 44 & Farm and Garden Machinery & 19,183 & 9,025 & .435 & .214 \\
\hline 45 & Construction machinery & 20,699 & 10,277 & .444 & .223 \\
\hline 46 & Materials handling machines & 16,782 & 10,277 & .459 & .253 \\
\hline 47 & Metalworking machinery & 18,093 & 8,897 & .445 & .222 \\
\hline 48 & Special industry machinery & 16,484 & 8,094 & .443 & .224 \\
\hline 49 & General industrial machinery & 16,942 & 8,094 & .443 & .221 \\
\hline 50 & Miscellaneous machinery & 16,528 & 8,094 & .484 & .242 \\
\hline 51 & office \& computing machinery & 16,951 & 12,398 & .538 & .340 \\
\hline 52 & Service industry machines & 15,352 & 8,094 & .425 & .222 \\
\hline 53 & Electric industrial equip. & 15,000 & 8,383 & .434 & .237 \\
\hline 54 & Household appliances & 13,102 & 8,832 & .413 & .237 \\
\hline 55 & Electric lighting \& wire & 12,085 & 8,383 & .392 & .231 \\
\hline 56 & Radio, TV, and com. & 18,811 & 10,181 & .587 & .325 \\
\hline 57 & Electronic components & 13,146 & 8,383 & .629 & .367 \\
\hline 58 & Miscellaneous electrical & 18,006 & 8,383 & .469 & .235 \\
\hline 59 & Motor vehicle and equipment & 28,233 & 9,828 & .471 & .207 \\
\hline 60 & Aircraft and parts & 25,289 & 11,369 & .520 & .251 \\
\hline 61 & Other transportation equip. & 17,373 & 9.090 & .472 & .245 \\
\hline 62 & scientific equipment & 13,914 & 8,897 & .436 & .256 \\
\hline 63 & Optical \& ophthalmic equip. & 19.461 & 9.090 & .451 & .232 \\
\hline 64 & Miscellaneous manufacturing & 8,890 & 5,878 & .347 & .204 \\
\hline 65 & Transportation and warehouse & 18,667 & 8,512 & 440 & 213 \\
\hline
\end{tabular}


Table 1

Labor Rents by Commodity

\begin{tabular}{|c|c|c|c|c|}
\hline \multirow[b]{2}{*}{ Commodity } & \multicolumn{2}{|c|}{$\begin{array}{c}\text { Rents per Worker } \\
\text { Year }(1993 \$)\end{array}$} & \multicolumn{2}{|c|}{$\begin{array}{c}\text { Rents as Fraction } \\
\text { of value }\end{array}$} \\
\hline & $\begin{array}{c}\text { Raw } \\
\text { Compens. }\end{array}$ & $\begin{array}{l}\text { Cor. } \\
\text { Compens. }\end{array}$ & $\begin{array}{c}\text { Raw } \\
\text { Compens. }\end{array}$ & $\begin{array}{l}\text { Cor. } \\
\text { Compens. }\end{array}$ \\
\hline 66 Commun. except radio and $\mathrm{TV}$. & 21,599 & 12,622 & .455 & .263 \\
\hline 67 Radio and television & 15,359 & 7,227 & .379 & .191 \\
\hline 68 Private utilities & 21,327 & 12,140 & .219 & .123 \\
\hline 69 wholesale and retail trade & 7,576 & 4,046 & .325 & .177 \\
\hline 70 Finance and insurance & 12,682 & 8,254 & .421 & .265 \\
\hline 71 Real estate and rental & 4,254 & 5,171 & .154 & .092 \\
\hline 72 Hotels, personal and repair & 2,337 & 2,537 & .212 & .161 \\
\hline 73 Business Services & 10,487 & 6,745 & .325 & .195 \\
\hline 74 Eating and drinking places & 65 & 0 & .177 & .097 \\
\hline 75 Automobile repair and serv. & 14,824 & 4,817 & .372 & .159 \\
\hline 76 Amusements & 6,975 & 3,148 & .323 & .168 \\
\hline 77 Health \& educational & 6,166 & 5,331 & .325 & .247 \\
\hline
\end{tabular}


Table 2

Net Labor Rents as a Praction of Value For Domestic Industrial Policy

\begin{tabular}{|c|c|c|c|}
\hline \multicolumn{2}{|c|}{ commodity } & \multirow{2}{*}{$\begin{array}{l}\text { Raw } \\
\text { Compens. } \\
-.042\end{array}$} & \multirow{2}{*}{$\begin{array}{l}\text { Cor } \\
\text { Compens } \\
-.018\end{array}$} \\
\hline 1 & Livestock and products & & \\
\hline 2 & Other agricultural products & -.053 & -.015 \\
\hline 3 & Forestry and fisheries & -.040 & -.028 \\
\hline 4 & Agricultural services & -.251 & -.102 \\
\hline 5 & Iron and ferroalloy ores & .226 & .103 \\
\hline 6 & Nonferrous metal ores & .217 & .133 \\
\hline 7 & Coal mining & .228 & .136 \\
\hline 8 & Crude Petroleum and gas & .082 & .040 \\
\hline 9 & stone and clay mining & .115 & .072 \\
\hline 10 & Chemical and fertilizer & .125 & .056 \\
\hline 11 & New construction & .105 & .069 \\
\hline 12 & Repair and Maintenance & .149 & .079 \\
\hline 13 & Ordnance and accessories & .278 & .128 \\
\hline 14 & Food and kindred products & .052 & .012 \\
\hline 15 & Tobacco manufactures & .040 & .035 \\
\hline 16 & Broad and narrow fabrics & .024 & .029 \\
\hline 17 & Miscellaneous textile goods & .062 & .043 \\
\hline 18 & Apparel & -.138 & -.057 \\
\hline 19 & Misc. fab textile products & -.002 & -.013 \\
\hline 20 & Lumber and wood products & .059 & .009 \\
\hline 21 & Wood containers & -.088 & .009 \\
\hline 22 & Household Furniture & -.023 & .007 \\
\hline 23 & Other furniture fixtures & .087 & .012 \\
\hline 24 & Paper and Allied Products & .154 & .063 \\
\hline 25 & Paperboard containers & .139 & .048 \\
\hline 26 & Printing and Publishing & .109 & .031 \\
\hline 27 & Chemicals & .161 & .073 \\
\hline 28 & Plastics and synthetics & .192 & .071 \\
\hline 29 & Drugs, cleaning \& toilet & .126 & .053 \\
\hline 30 & Paints and allied products & .146 & .058 \\
\hline 31 & Petroleum refining & .107 & .048 \\
\hline 32 & Rubber and miscellaneous & .119 & .055 \\
\hline 33 & Leather tanning and finish & .078 & .019 \\
\hline
\end{tabular}


Table 2

Net Labor Rents as a Fraction of Value For Domestic Indugtrial Policy

\begin{tabular}{|c|c|c|c|}
\hline \multicolumn{2}{|c|}{ commodity } & \multirow{2}{*}{$\begin{array}{l}\text { Raw } \\
\text { Compens. } \\
-.117\end{array}$} & \multirow{2}{*}{$\begin{array}{l}\text { Cor. } \\
\text { compens } \\
-.017\end{array}$} \\
\hline 34 & Footwear and other leather & & \\
\hline 35 & Glass and glass products & .176 & .050 \\
\hline 36 & stone and clay products & .131 & .049 \\
\hline 37 & Primary iron and steel & .237 & .069 \\
\hline 38 & Primary nonferrous metals & .162 & .058 \\
\hline 39 & Metal containers & .204 & .044 \\
\hline 40 & Heating and plumbing & .145 & .047 \\
\hline 41 & Screw machine products & .205 & .049 \\
\hline 42 & Other fabricated metal & .129 & .048 \\
\hline 43 & Engines and Turbines & .215 & .090 \\
\hline 44 & Farm and Garden Machinery & .180 & .062 \\
\hline 45 & Construction machinery & .198 & .075 \\
\hline 46 & Materials handling machines & .162 & .081 \\
\hline 47 & Metalworking machinery & .189 & .069 \\
\hline 48 & special industry machinery & .164 & .057 \\
\hline 49 & General industrial machinery & .164 & .054 \\
\hline 50 & Miscellaneous machinery & .181 & .062 \\
\hline 51 & office \& computing machinery & .144 & .112 \\
\hline 52 & Service industry machines & .136 & .052 \\
\hline 53 & Electric industrial equipment & .139 & .062 \\
\hline 54 & Household appliances & .109 & .060 \\
\hline 55 & Electric lighting \& wire & .096 & .058 \\
\hline 56 & Radio, TV, and com. & .184 & .089 \\
\hline 57 & Electronic components & .109 & .067 \\
\hline 58 & Miscellaneous electrical & .167 & .057 \\
\hline 59 & Motor vehicle and equipment & .223 & .057 \\
\hline 60 & Aircraft and parts & .260 & .095 \\
\hline 61 & other transportation equip. & .179 & .071 \\
\hline 62 & Scientific equipment & .117 & .070 \\
\hline 63 & Optical \& ophthalmic equip. & .148 & .054 \\
\hline 64 & Miscellaneous manufacturing & .037 & .021 \\
\hline 65 & Transportation and warehouse & .192 & .063 \\
\hline 66 & Commun except radio and TV, & 196 & 111 \\
\hline
\end{tabular}


Table 2

Net Labor Rents as a Fraction of Value For Domestic Industrial Policy

\begin{tabular}{lcc}
\hline Commodity & $\begin{array}{c}\text { Raw } \\
\text { compens. }\end{array}$ & $\begin{array}{c}\text { Cor. } \\
\text { compens. }\end{array}$ \\
\hline 67 Radio and television & .087 & .020 \\
68 Private utilities & .110 & .058 \\
69 wholesale and retail trade & -.038 & -.037 \\
70 Finance and insurance & .087 & .068 \\
71 Real estate and rental & .031 & .019 \\
72 Hotels, personal and repair & -.218 & -.094 \\
73 Business Services & .035 & .028 \\
74 Eating and drinking places & -.307 & -.191 \\
75 Automobile repair and serv. & .118 & .008 \\
76 Amusements & -.033 & -.043 \\
77 Health \& educational & -.107 & -.008
\end{tabular}


Table 3

Net Labor Rents as a Fraction of Value For Trade Policy

\begin{tabular}{|c|c|c|c|c|c|}
\hline & & \multicolumn{2}{|c|}{$\begin{array}{l}\text { Rents Net of Labor } \\
\text { Use in Marginal } \\
\text { commodity }\end{array}$} & \multicolumn{2}{|c|}{$\begin{array}{l}\text { Rents Net of Labor } \\
\text { Use in Average } \\
\text { commadity }\end{array}$} \\
\hline \multicolumn{2}{|c|}{ Commodity } & $\begin{array}{l}\text { Raw } \\
\text { Compens. }\end{array}$ & $\begin{array}{l}\text { Cor. } \\
\text { compens. }\end{array}$ & $\begin{array}{l}\text { Raw } \\
\text { Compens. }\end{array}$ & $\begin{array}{l}\text { Cor. } \\
\text { compens. }\end{array}$ \\
\hline 1 & Livestock and products & -.155 & -.064 & -.148 & -.060 \\
\hline 2 & Other agricultural products & -.173 & -.065 & -.167 & -.060 \\
\hline 3 & Forestry and fisheries & -.168 & -.078 & -.161 & -.074 \\
\hline 4 & Agricultural services & -.353 & -.143 & -.346 & -.139 \\
\hline 5 & Iron and ferroalloy ores & .149 & .077 & .155 & .081 \\
\hline 6 & Nonferrous metal ores & .126 & .098 & .133 & .103 \\
\hline 7 & Coal mining & .119 & .092 & .126 & .096 \\
\hline 8 & Crude Petroleum and gas & -.034 & -.008 & -.027 & -.004 \\
\hline 9 & Stone and clay mining & -.006 & .020 & .001 & .025 \\
\hline 10 & Chemical and fertilizer & .004 & .005 & .011 & .010 \\
\hline 11 & New construction & -.025 & .015 & -.018 & .019 \\
\hline 12 & Repair and Maintenance & .012 & .023 & .019 & .028 \\
\hline 13 & ordnance and accessories & .156 & .078 & .163 & .082 \\
\hline 14 & Food and kindred products & -.072 & -.039 & -.065 & -.035 \\
\hline 15 & Tobacco manufactures & -.079 & -.017 & -.072 & -.013 \\
\hline 16 & Broad and narrow fabrics & -.105 & -.023 & -.099 & -.018 \\
\hline 17 & Miscellaneous textile goods & -.062 & -.008 & -.055 & -.003 \\
\hline 18 & Apparel & -.277 & -.113 & -.270 & -.109 \\
\hline 19 & Misc. fab textile products & -.133 & -.062 & -.126 & -.058 \\
\hline 20 & Lumber and wood products & -.072 & -.044 & -.065 & -.040 \\
\hline 21 & wood containers & -.211 & -.048 & -.205 & -.043 \\
\hline 22 & Household Furniture & -.156 & -.048 & -.149 & -.044 \\
\hline 23 & Other furniture fixtures & -.045 & -.041 & -.038 & -.037 \\
\hline 24 & Paper and Allied Products & .025 & .009 & .031 & .014 \\
\hline 25 & Paperboard containers & .004 & -.008 & .011 & -.003 \\
\hline 26 & Printing and Publishing & -.023 & -.023 & -.016 & -.019 \\
\hline 27 & Chemicals & .030 & .017 & .037 & .021 \\
\hline 28 & Plastics and synthetics & .067 & .023 & .073 & .027 \\
\hline 29 & Drugs, cleaning \& toilet & -.001 & .000 & .006 & .004 \\
\hline 30 & Paints and allied products & .015 & .003 & .022 & .008 \\
\hline 31 & Petroleum refining & -.017 & -.004 & -.010 & .001 \\
\hline
\end{tabular}


Table 3

Net Labor Rents as a Fraction of Value For Trade Policy

\begin{tabular}{|c|c|c|c|c|c|}
\hline & & \multicolumn{2}{|c|}{$\begin{array}{l}\text { Rents Net of Labor } \\
\text { Use in Marginal } \\
\text { Commadity }\end{array}$} & \multicolumn{2}{|c|}{$\begin{array}{l}\text { Rents Net of Labor } \\
\text { Use in Average } \\
\text { commodity }\end{array}$} \\
\hline \multicolumn{2}{|c|}{ Commodity } & $\begin{array}{l}\text { Raw } \\
\text { Compens. }\end{array}$ & $\begin{array}{l}\text { Cor. } \\
\text { Compens. }\end{array}$ & $\begin{array}{l}\text { Raw } \\
\text { compens. }\end{array}$ & $\begin{array}{l}\text { Cor } \\
\text { Compens }\end{array}$ \\
\hline 32 & Rubber and miscellaneous & -.004 & .004 & .003 & .009 \\
\hline 33 & Leather tanning and finish & -.054 & -.035 & -.048 & -.031 \\
\hline 34 & Footwear and other leather & -.254 & -.073 & -.247 & -.069 \\
\hline 35 & Glass and glass products & .046 & -.003 & .053 & .002 \\
\hline 36 & Stone and clay products & .000 & -.005 & .007 & .000 \\
\hline 37 & Primary iron and steel & .100 & .014 & .106 & .018 \\
\hline 38 & Primary nonferrous metals & .025 & .002 & .032 & .006 \\
\hline 39 & Metal containers & .067 & -.011 & .074 & -.006 \\
\hline 40 & Heating and plumbing & .017 & -.005 & .023 & -.001 \\
\hline 41 & Screw machine products & .070 & -.005 & .077 & .000 \\
\hline 42 & other fabricated metal & .001 & -.006 & .007 & -.001 \\
\hline 43 & Engines and Turbines & .080 & .033 & .087 & .038 \\
\hline 44 & Farm and Garden Machinery & .048 & .008 & .055 & .012 \\
\hline 45 & Construction machinery & .062 & .019 & .069 & .023 \\
\hline 46 & Materials handling machines & .037 & .027 & .043 & .031 \\
\hline 47 & Metalworking machinery & .052 & .012 & .059 & .017 \\
\hline 48 & Special industry machinery & .030 & .003 & .037 & .007 \\
\hline 49 & General industrial machinery & .033 & .001 & .040 & .006 \\
\hline 50 & Miscellaneous machinery & .047 & .008 & .054 & .012 \\
\hline 51 & office \& computing machinery & .031 & .064 & .037 & .069 \\
\hline 52 & Service industry machines & .009 & -.001 & .016 & .004 \\
\hline 53 & Electric industrial equip. & .009 & .009 & .016 & .013 \\
\hline 54 & Household appliances & -.015 & .007 & -.008 & .012 \\
\hline 55 & Electric lighting \& wire & -.029 & .004 & -.023 & .009 \\
\hline 56 & Radio, TV, and com. & .071 & .044 & .078 & .048 \\
\hline 57 & Electronic components & .013 & .029 & .020 & .034 \\
\hline 58 & Miscellaneous electrical & .042 & .006 & .048 & .010 \\
\hline 59 & Motor vehicle and equipment & .089 & .004 & .096 & .008 \\
\hline 60 & Aircraft and parts & .125 & .041 & .132 & .045 \\
\hline 61 & other transportation equip. & .045 & .016 & .052 & .020 \\
\hline 62 & Scientific equipment & -.010 & .016 & -.003 & .021 \\
\hline 63 & optical \& ophthalmic equip. & .034 & .008 & .040 & 012 \\
\hline
\end{tabular}


Table 3

Net Labor Rents as a Fraction of Value For Trade Policy

\begin{tabular}{|c|c|c|c|c|c|}
\hline \multirow{2}{*}{\multicolumn{2}{|c|}{ Commodity }} & \multicolumn{2}{|c|}{$\begin{array}{l}\text { Rents Net of Labor } \\
\text { Use in Marginal } \\
\text { Commodity }\end{array}$} & \multicolumn{2}{|c|}{$\begin{array}{l}\text { Rents Net of Labor } \\
\text { Use in Average } \\
\text { commodity }\end{array}$} \\
\hline & & \multirow{2}{*}{$\begin{array}{l}\text { Raw } \\
\text { Compens. } \\
-.094\end{array}$} & \multirow{2}{*}{$\begin{array}{l}\text { Cor. } \\
\text { Compens. } \\
-.033\end{array}$} & \multirow{2}{*}{$\begin{array}{l}\text { Raw } \\
\text { compens } \\
-.087\end{array}$} & \multirow{2}{*}{$\begin{array}{l}\text { Cor. } \\
\text { compens } \\
-.029\end{array}$} \\
\hline 64 & Miscellaneous manufacturing & & & & \\
\hline 65 & Transportation and warehouse & .054 & .007 & .061 & .011 \\
\hline 66 & Commun. except radio and $\mathrm{TV}$. & .074 & .060 & .081 & .065 \\
\hline 67 & Radio and television & -.038 & -.033 & -.032 & -.028 \\
\hline 68 & Private utilities & -.026 & -.001 & -.019 & .003 \\
\hline 69 & Wholesale and retail trade & -.168 & -.090 & -.162 & -.086 \\
\hline 70 & Finance and insurance & -.041 & .016 & -.034 & .020 \\
\hline 71 & Real estate and rental & -.084 & -.029 & -.077 & -.025 \\
\hline 72 & Hotels, personal and repair & -.359 & -.151 & -.352 & -.147 \\
\hline 73 & Business Services & -.086 & -.026 & -.079 & -.021 \\
\hline 74 & Eating and drinking places & -.449 & -.247 & -.443 & -.243 \\
\hline 75 & Automobile repair and serv. & -.009 & -.045 & -.002 & -.040 \\
\hline 76 & Amusements & -.165 & -.097 & -.159 & -.093 \\
\hline 77 & Health \& educational. & -247 & -065 & -241 & -061 \\
\hline
\end{tabular}

